Session 1151

\title{
Environmental Engineering and the World Water Vision
}

\author{
Joseph J. Delfino \\ Environmental Engineering Sciences \\ University of Florida, Gainesville
}

\begin{abstract}
The World Water Commission, in conjunction with the World Water Council, the Global Environmental Partnership, and the World Bank, has released its World Water Vision report entitled A Water Secure World. ${ }^{1}$ Among various supporting documents is the report Towards Water Security: A Framework for Action ${ }^{2}$, wherein plans for implementing the World Water Vision over the next 25 years are discussed. It is clear that many areas of the world are facing a water "crisis." The vision's goal is to provide water security for the world's citizens in the $21{ }^{\text {st }}$ Century. Several goals include insuring that every person has access to enough safe water at affordable cost [which implies a drive toward water privatization on a global scale], and that water resources are protected and improved. The task is challenging and the funding requirements to meet the goals will be enormous. To date, the engineering component of the process of transforming "the vision to action" has not been fully described. This paper will analyze the World Water Vision from an environmental engineering perspective, and will discuss the role that environmental engineers can play in seeing that the "Vision" is turned into "Action."
\end{abstract}

\section{Introduction}

The World Water Vision is a striking example of an international effort designed to provide "water security" for the world's population by the year 2025. An impossible dream? Perhaps. But there are many people in many countries developing plans to try to achieve this goal. Speaking at the Second World Water Forum and Ministerial Conference held in The Hague, The Netherlands, in March, 2000, Dr. Mahmoud AbuZeid, President of the World Water Council, summarized the World Water Vision process to that date. ${ }^{3}$ In brief, the Vision traces its origin to ideas generated at the 1992 Dublin Conference on Water and the Environment. However, later in that year at the Rio de Janeiro Earth Summit, establishment of a World Water Commission wasn't approved. Subsequent conferences endorsed this concept and a resolution approved in 1994 at the $8^{\text {th }}$ World Water Congress in Cairo, Egypt established the Commission. Founding 
Committee meetings were held in 1995-96 in Montreal, Bari, Marseilles, and again in 1997, in Montreal at the $9^{\text {th }}$ World Water Congress of the International Water Resources Association. The $1^{\text {st }}$ World Water Forum held in Marrakech, Morocco in 1997 issued the "Declaration" that mandated the World Water Commission to develop the Vision for World Water, Life and Environment for the $21^{\text {st }}$ Century. The Commission's subsequent activities led to the numerous Vision reports that were issued at the $2^{\text {nd }}$ World Water Forum held in 2000, in the Hague, The Netherlands, some of which appear in the bibliography section of this paper. Various Web sites have also been established for the dissemination of the Vision documents. ${ }^{4}$

The international engineering community has been involved in many water-related activities, particularly through the auspices of the World Federation of Engineering Organizations (WFEO) and its Committee on Technology (ComTech). ${ }^{5}$ Through early meetings held with the World Bank, and then at its General Assembly in 1997 in Hong Kong, the WFEO passed a resolution on "Freshwater Sustainability" and it charged its many participating organizations to manage global water issues at the national level. In 1998, ComTech sponsored a panel discussion at the U.N. Commission on Sustainable Development's intersession meeting, ${ }^{6}$ illustrating the movement toward privatization of water development in areas of the world that have serious water shortage problems. This is a recurring theme in Vision reports as well. ${ }^{1,2,3}$ Water was also a feature in ComTech's subsequent U.N.C.S.D. panel discussions in 1999 and $2000{ }^{7}$

The Vision reports and the documentation from the $2^{\text {nd }}$ World Water Forum in The Hague were made available for additional scrutiny and discussion in Stockholm in August, 2000 during the annual World Water Week. ${ }^{8}$ The Stockholm Water Symposium is yet another international forum for the discussion of world water issues and crises. ${ }^{9}$ As the $21^{\text {st }}$ Century unfolds, the World Water Council has established a busy agenda. Keeping in minds its goal of water security for the world's citizens by 2025, the Council will be establishing a monitoring system for the Vision, seeking private funding for world water development, focusing on water in Asia during the $3^{\text {rd }}$ World Water Forum which will be staged in 2003 in Asia, studying hygiene and sanitation and reporting its results to the U.N. in 2004, and, finally, emphasizing successful models for the sharing of water among many nations. ${ }^{3}$ Clearly, the World Water Council will be very active and the success of its goals will depend on an extraordinary amount of international cooperation.

\section{Environmental Engineers and The World Water Vision}

A major component of the work performed by environmental engineers focuses on water. This involves just about every facet of the hydrologic cycle, starting with the capture and 
management of precipitation, advancing to the treatment and delivery of water to consumers and to agriculture, and concluding with the treatment and disposal of water borne wastes. Water and wastewater treatment are so fundamental to the field that many textbooks devote many chapters to the topic. ${ }^{10,11,12}$ Hundreds and likely thousands of environmental engineers have been educated and trained in recent decades to solve problems related to water supply, water pollution control, hydrology, flood control, etc. So, the question arises, "why is there a global water crisis if the basic concepts and engineering processes needed to solve the crisis are so well known?"

Clearly, among the many and varied answers that can be suggested for this question, depending on the region and countries involved, are: (a) uncertain and poorly distributed annual precipitation; (b) unsatisfactory or nonexistent precipitation capture and storage structures; (c) water demand and use in excess of available and accessible supply, including competition between potable and agricultural needs; (d) inadequate pollution control facilities resulting in contamination of available resources; (e) lack of political will and insufficient financial investment in water infrastructure; $(\mathrm{g})$ inter-national agreements or disputes that restrict water availability to "downstream" users; and (f) too few trained professionals involved in water issues.

Each of these issues has been and will continue to be the subject of papers, books and dissertations, some of which will eventually capture the imaginations of local, national, regional and international leaders, perhaps ultimately leading to resolution of many of the important problems. This is the hope of the World Water Vision process. An example of such leadership is being provided by the Hon. Mikhail Gorbachev, former President of the U.S.S.R., and now President of Green Cross International. His organization is addressing water security issues in many areas of the world, including the Middle East, ${ }^{13}$ even while intense political and social differences persist.

Beyond the Middle East, the Global Water Partnership (GWP) is stimulating World Water Vision activity in many regions of the world where economically developing nations are trying to address mutual water problems. An example is the consultative process that occurred in Central and Eastern Europe, resulting in the formation of a Regional Technical Advisory Committee which issued a report at the $2^{\text {nd }}$ World Water Forum in conjunction with the GWP. ${ }^{14}$ Environmental engineers need to take direct action, or stimulate others to take action, to address many serious water issues (the severity of these varies among the 10 countries in this region but they are none-the-less representative). These include: (a) develop the political will to address water issues, including lobbying to educate politicians about their importance; (b) stimulate publicprivate partnerships and accompanying regulatory initiatives; (c) identify risks associated with water resource management; (d) identify "owners" of water resources in the context 
of national and international laws and agreements; (e) establish and enforce the separate roles of government in setting policy and the engineering community in designing, constructing and operating water facilities; (f) establish a water quality monitoring network with clearly stated objectives, and develop systems to share data once their quality has been assured; (g) comply with European Union (E.U.) resource and pollution control directives to enable developing countries to gain entrance into the E.U.; (h) investigate practicalities of privatizing water utilities and establishing fair pricing for water; ( $\mathrm{i}$ ) study appropriate technologies to apply to urban and rural pollution control needs that will protect surface and ground water resources; (j) implement geographic information systems into water resources planning and management; (k) encourage public participation in water development issues, a process that doesn't enjoy a long history in several countries; (1) introduce ISO 14000 standards for environmental management in the region; $(\mathrm{m})$ reduce pollutant discharge loadings to improve ambient water quality; (n) develop and apply regional water quality planning models to improve cost-effectiveness of pollution control strategies; (o) encourage sustainable agricultural practices to reduce non-point source loading to receiving waters; (p) implement pollution prevention strategies in production facilities; $(\mathrm{q})$ reduce water consumption by encouraging conservation and reuse; ( $\mathrm{r}$ ) improve flood control and flood protection; and (s) work toward implementing international integrated water resources management. This list could go on and on, but it serves to illustrate the extent of environmental engineering involvement that will be necessary in just one region of the world as it seeks to implement its Water Vision.

\section{Engineering Education and the World Water Vision}

The World Water Vision can succeed through the efforts of thousands of individuals throughout the world working toward the common goal of insuring water security, perhaps even by the present target date of 2025. However, as indicated above, the role of environmental engineers (including environmentally oriented civil, chemical and mechanical engineers) is critical to this process. Assuming that political will and financial support are available, can the environmental engineering community meet the challenges of the World Water Vision?

There is a major uncertainty. Will there be enough educated and trained environmental and civil engineers to do the jobs necessary to provide water security throughout the world? As of early 2001, the answer may be no! There is presently more demand for educated and trained environmental engineers than there are professionals available to do the work. ${ }^{15,16}$ In the U.S.A., there is high demand for environmental engineers in the area of water supply and wastewater treatment infrastructure development and replacement. These are the facilities that don't yet exist in many developing countries. If we cannot fill 
positions in the U.S.A. to replace existing facilities as they age, or design and build new ones where needed, it will be a challenge to find environmental and civil engineers to meet the needs of the developing nations that have minimal infrastructure today.

The World Water Commission is encouraging privatization and fair pricing for water, as indicated earlier, as one way to encourage water resources development and water conservation. The plan is for market forces to insure water availability. The global water industry is in a period of consolidation, with considerable merger and acquisition activity occurring and this is predicted to continue. It is estimated that over $\$ 1$ trillion will be needed in the U.S.A., alone, to upgrade and replace the water infrastructure in the next 20 years. ${ }^{17}$ The Federal government is unlikely to provide very much funding. Global costs for infrastructure development will exceed the estimated U.S.A. costs since, in many countries, water and wastewater systems simply don't exist at this time.

As the water and wastewater market expands on a global basis in response to infrastructure renovation in developed countries and new construction in developing countries, new challenges await environmental engineers. In particular, for U.S.A. trained engineers, it will be important for them to learn the nuances of working overseas. This is particularly important in areas such as bidding and implementing work plans in various cultures. U.S.A. trained engineers will need to learn about issues such as grease payments, gifts to facilitate work progress, bribery, and extortion. The importance of ethics courses for environmental engineers cannot be underestimated in this regard. ${ }^{18}$

If the World Bank, the Global Water Partnership and the Global Environmental Facility intend to assist developing nations with grants and loans to meet the World Water Vision objectives, then they will need to include an education component in their plans. Otherwise, there will be many projects that won't be completed due to the lack of sufficient numbers of educated and trained environmental and civil engineers. The solution to the environmental engineering availability problem will have to involve a combination of support for initiating or increasing engineering education in the developing nations while also providing financial support for students in those countries to attend engineering colleges in developed nations. Part of this support should go toward increasing faculties and facilities in the developing nations and scholarship and fellowship funding for study abroad. Failure to include an education and training component in the World Water Vision process will result in a longer time frame to meet the stated objectives. There has been very little direct discussion of this issue in the World Water Vision documents, perhaps due to the lack of engineers and educators on the critical commissions and councils that are developing the plans for the Vision. It is possible that the environmental engineering community has not sensitized policy makers to the need for sustained environmental engineering education at home and abroad.

Proceedings of the 2001 American Society for Engineering Education Annual Conference \& Exposition Copyright $\odot$ 2001, American Society for Engineering Education 
The World Water Vision process can be successful. Environmental engineers will need to take active roles on a global basis to insure that the Vision's objectives will be met by the year 2025, which is the present target for achieving water security on a global scale.

Bibliography

1. World Commission for Water in the $21^{\text {st }}$ Century. A Water Secure World. Marseilles, France: World Water Council (2000).

2. Framework for Action Unit. Towards Water Security: A Framework for Action. Stockholm, Sweden: Global Water Partnership (2000).

3. Abu-Zeid, M. The road map to World Water in the $21^{\text {st }}$ Century. Marseilles, France: World Water Council (2000).

4. URLs: http://WwW. for worldwatercouncil.org; watervision.org; gwpforum.org.

5. World Federation of Engineering Organizations. ComTech News, Vol. 4 (3), July-September.

Washington, D.C.: American Association of Engineering Societies (2000).

6. World Federation of Engineering Organizations, Committee on Technology. The Engineers' Report:

Water Privatization Projects in the Developing World. Washington, D.C.: American Association of

Engineering Societies (1998).

7. World Federation of Engineering Organizations, Committee on Technology. The Engineers' Report:

Production Efficiencies ; and The Engineers' Report: Sustainable Agriculture. Washington, D.C.: American Association of Engineering Societies (1999) and (2000).

8. World Water Council. Final Report, $2^{\text {nd }}$ World Water Forum. The Hague: Water Management Unit c/o Ministry of Foreign Affairs (2000).

9. Stockholm International Water Institute. Water Front - A Forum for Global Water Issues, No. 3, October. Stockholm, Sweden: SIWI (2000).

10. Weber, W.J., Jr. and DiGiano, F.A. Process Dynamics in Environmental Systems. New York, N.Y.: J. Wiley \& Sons, Inc. (1996).

11. Sincero, A.P. and Sincero, G.A. Environmental Engineering - A Design Approach. Upper Saddle River, N.J.: Prentice Hall, Inc. (1996).

12. Davis, M.L. and Cornwell, D.F. Introduction to Environmental Engineering, $3^{\text {rd }}$ Ed. Boston, Mass.: WCB/McGraw-Hill (1998).

13. Green Cross International. National Sovereignty and International Watercourses. Geneva: Green Cross International (2000).

14. Central and Eastern Europe Regional Technical Advisory Committee. Water for the $21^{\text {st }}$ Century: Vision to Action - Central \& Eastern Europe. Stockholm, Sweden: Global Water Partnership (2000).

15. Goode, M.G. The State of International Affairs. A Civil Engineered World (ASCE), Vol. 14(1) (2001). 16. Delfino, J.J. Enrollment and Job Placement Statistics (unpublished). Department of Environmental Engineering Sciences, Univ. of Florida, Gainesville, Florida (2001).

17. Byrne, H.S. Precious Fluid. Barron's, Vol. 81(10), pp. 27-30 (2001).

18. Harris, Jr., C.E., Pritchard, M.S. and Rabins, M.J. Engineering Ethics: Concepts and Cases, $2^{\text {nd }}$ Ed. Belmont Cal.: Wadsworth/Thompson Learning (2000).

\section{JOSEPH J. DELFINO}

Joseph J. Delfino is Professor and Past Chairman of Environmental Engineering Sciences at the University of Florida, Gainesville, Florida. He earned his Ph.D. in Civil and Environmental Engineering with a specialty in Water Chemistry at the University of Wisconsin-Madison. Prior to joining the faculty at the University of Florida, he was Professor of Civil and Environmental Engineering at the University of Wisconsin-Madison, where he was also Head of Environmental Sciences for the State Laboratory of Hygiene and Associate Director of the Water Resources Center. He teaches courses and conducts research in water chemistry and water quality analysis and is the Department's Graduate Program Coordinator.

Proceedings of the 2001 American Society for Engineering Education Annual Conference \& Exposition Copyright $\odot$ 2001, American Society for Engineering Education 